The BDJ News section accepts items that include general news, latest research and diary events that interest our readers. Press releases or articles may be edited, and should include a colour photograph if possible. Please direct your correspondence to the News Editor, Arveen Bajaj at the BDJ, 64 Wimpole Street WIG 8YS or by email to bdj@bda.org

\section{CPD online}

The Eastman have announced that the BDJ online CPD programme now has in excess of 5,000 registered users.

As a result of the success of this continuing education project, the Eastman shall be inviting online submissions only, free of charge, for BDA members from April, whilst all paper submissions (post or fax) will attract a $£ 10$ charge for BDA members and nonBDA members in order to cover administrative costs.

\section{eastman}

CONTINUING PROFESSIONAL
DEVELOPMENT DEVELOPMENT

\section{Hungarian honours}

Dr David Ferguson was awarded an honorary doctorate of Semmelweiss Medical and Dental University, Budapest. The citation referred to his research and teaching in Manchester, his editorship of Archives of Oral Biology, his textbooks on physiology and oral bioscience and his edited books on oral physiology. Dr Ferguson has a long association in salivary research and teaching at the University.

Since his retirement from Manchester Dental School he has been involved in areas including teaching in oral biology in Hungary and advising on curriculum development and problem based learning in South Korea.

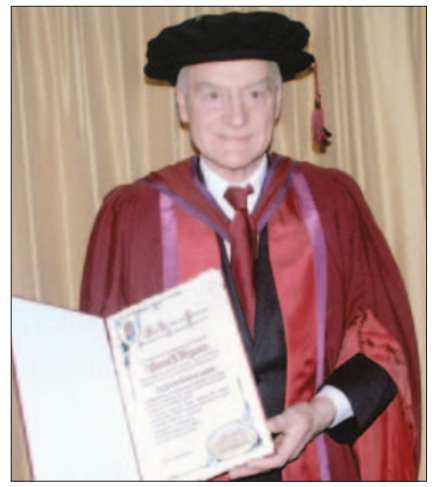

\section{Decennial celebrations}

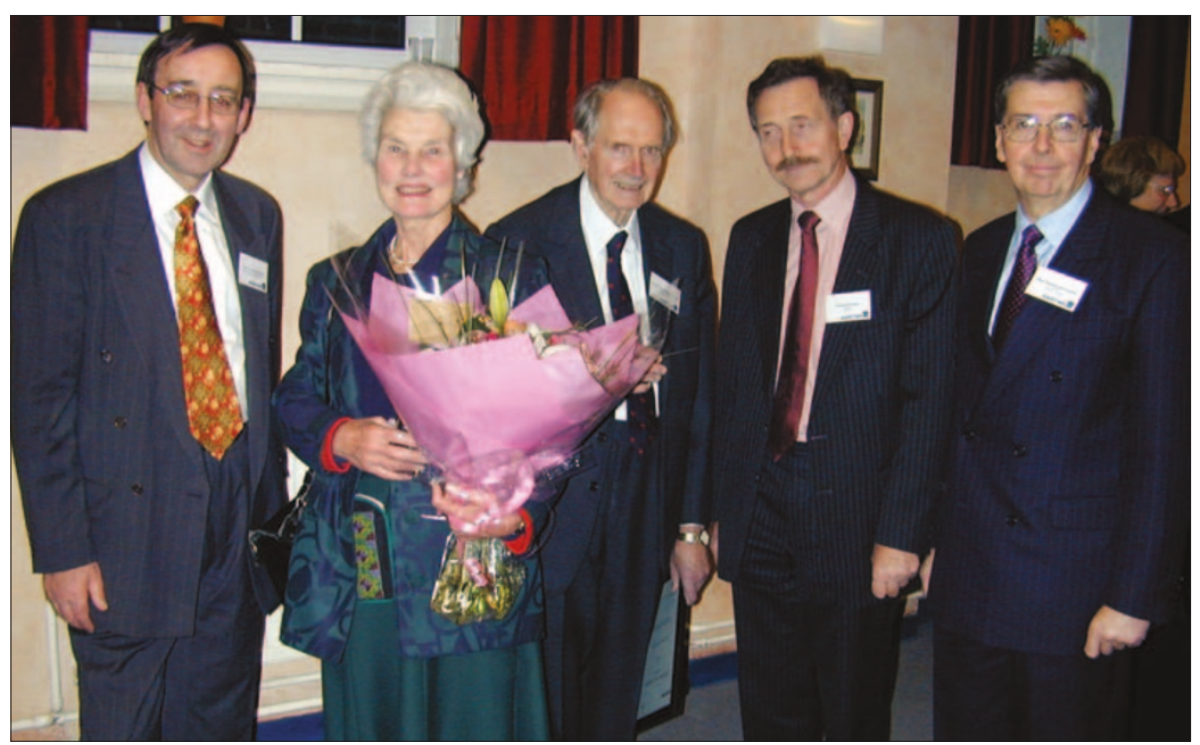

Professor Crispian Scully CBE marked the tenth anniversary of his appointment as Dean and Director of Studies and Research at the Eastman Dental Institute by hosting a reception for professional colleagues, friends and current and former staff. Dr Kenneth Eaton, Chairman of the Trustees of the Eastman Foundation for Oral Research and Training (EFFORT) also announced a new PhD Fellowship to start from October 2004. It will be targeted towards clinical or non-laboratory science projects such as public health, statistics, bio-informatics and clinical studies. Details can be found on the Eastman website at www. eastman.ucl.ac.uk. (Pictured from left to right: Professor Crispian Scully, former Chairman Lady Limerick, Mr Michael Edwards, Dr Kenneth Eaton, Chairman of EFFORT, and Major General John Gamon, President of the Eastman Academy).

\section{Success in smoking cessation}

Dentists in Coventry are helping patients who want to give up smoking in an initiative set up by the area's smoking cessation team.

More than 1000 people used Coventry's Smoking Cessation Service in the first three months of the year, which has helped more than 500 smokers to quit long-term.

Now the team is distributing cards (pictured right) to all dental practices in the area for patients to have.

The high rate of success in the area has in part been attributed to the flexibility of the services on offer.

Sessions are run at weekends as well as in the evenings at convenient locations and the service also provides nicotine replacement patches.

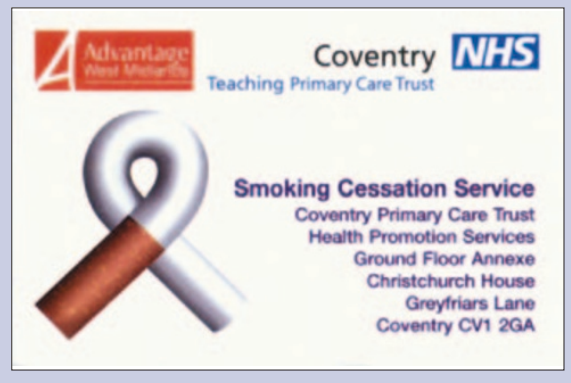

Your Dental Practitioner supporting you to stop

- Smoking

- Chewing tobacco

For Free Quit-Smoking Groups \& Nicotine Patches

Tel: Coventry Smoking Cessation Service on (024) 76246093

Don't give up giving up 


\section{DIARY}

April 2004

1st European Conference on Preventive \& Minimally Invasive Dentistry

Date: 16-17.04.04

Venue: Copenhagen

Contact: Conference office

Tel: +45 45937028

Fax: +45 45937029

Email:pc@quintessence.dk

Methodological Issues in Oral Health

Research

Date: 21-23.04.04

Venue: Leuven, Belgium

Contact: Secretariat

Tel: +32 (0) 16336892

Email: dental2001@med.kuleuven.ac.be www.kuleuven.ac.be/biostat/dental2004

May 2004

British Dental Conference and Exhibition

Date: 06-08.05.04

Contact: Delegate Management Services

Venue: Bournemouth International

Centre (BIC)

Tel: 08701666625 or + 44 (0) 1252

771425 (from overseas)

Fax: 08705228890 or + 44 (0) 1252

771790 (from overseas)

www.bda-events.org

Teaching Challenges for Changing Times

Date: 11.05 .04

Venue: University of Liverpool

Contact: Dr Lesley Longman

Tel: +44 (0) 1517065110

Fax: +44 (0) 1517065807

Email: Iplong@liverpool.ac.uk

\section{All change at Sheffield}

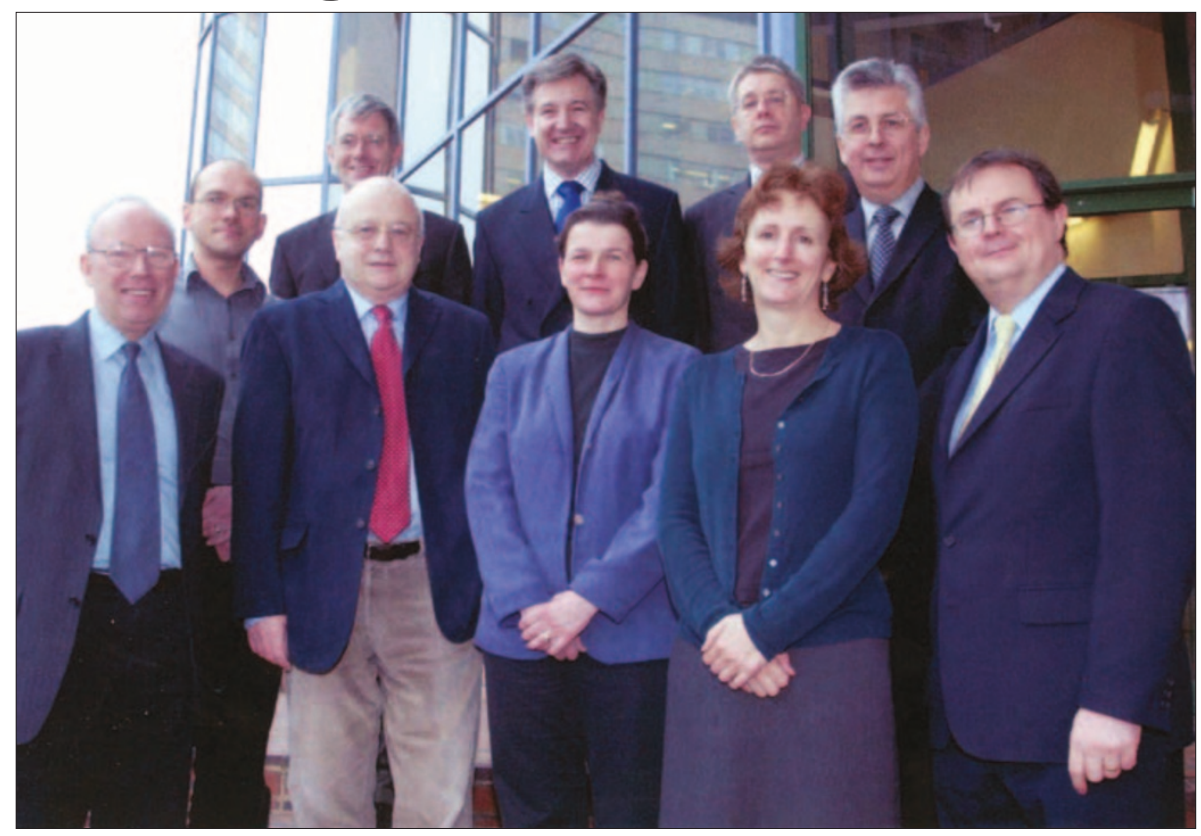

The School of Clinical Dentistry at the University of Sheffield has seen a number of recent staff changes due to a series of appointments.

Former Dean of the School Professor Alan Brook becomes the first dentist to be appointed Dean of the Faculty of Medicine, while Professor Trevor Walsh succeeds him as Dean of the School.

Professor Ric van Noort has become Head of the Department of Adult Dental Care while Professor Paul Speight has taken over as Head of the Department of Oral Pathology following the retirement of Professor Colin Smith.

He is joined by Dr Paula Farthing as senior lecturer and Dr Simon Whawell as lecturer. Professor Mike Lennon has been appointed to manage the Team Training Outreach Research Project and Dr G. T. Craig is Dean of Learning and Teaching.

Finally the School has made three new Chair appointments. Professor Peter G. Robinson was appointed to a new Chair in Dental Public Health and is joined by Dr Barry Gibson as lecturer in Sociology.

Fiona Boissonade and Paul Hatton, formerly Readers at the School have been appointed to Chairs of Oral Neuroscience and of Biomaterials respectively.

(Pictured back row left to right: Simon Whawell, Michael Smith, Alan Brook, Peter Robinson and Paul Speight. Front row left to right: Trevor Walsh, Mike Lennon, Fiona Boissonade, Paula Farthing and Paul Hatton). 


\section{On course for study}

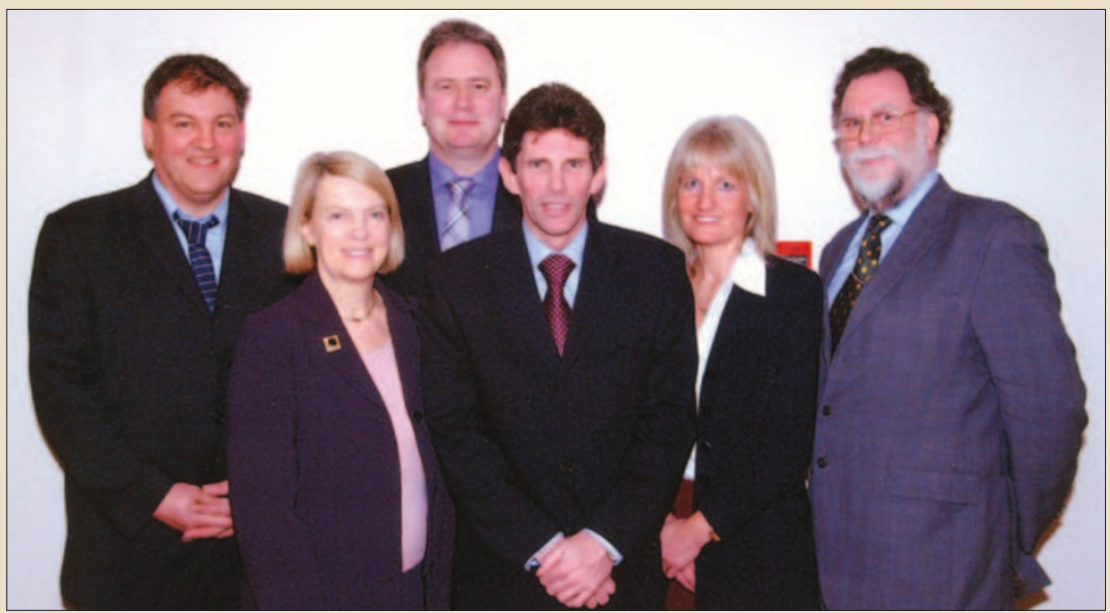

For the first time ever, students in Northern Ireland will be able to study for a Postgraduate Diploma in Dental Studies. Previously students had to travel to Bristol to undertake the course which will be run in the Northern Health and Social Services Board area in partnership with Bristol University and South West Postgraduate Deanery. Ten students are currently enrolled on the course. (Pictured left to right: Adrian Millen, Doreen Wilson, Professor Richard Welbury, Terry Gregg, Dr Janice Fearne and Peter Crawford at an information evening on postgraduate study).

\section{Success for Cork students}

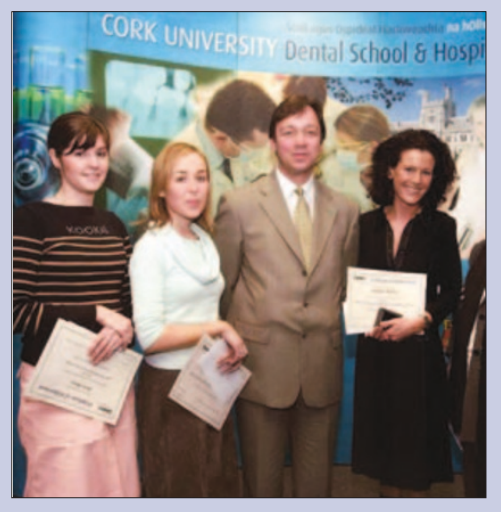

Four dental students from Cork University Dental School and Hospital received awards at a recent ceremony. Ciara Brown won the Dentsply prize in Anaesthetics, Aisling Feeney won the Ann Wilson Dentsply prize in Pharmacology, Dominque Brindley won the Dr Noel Hayes prize in Dental Surgery and student dental hygienist Caroline Keating won the Tutors' Award for the most caring student. (Pictured left to right: Ciara Brown, Aisling Feeney, Dentsply General Manager Peter Rees and Dominque Brindley.

\section{Dartford practice receives liP}

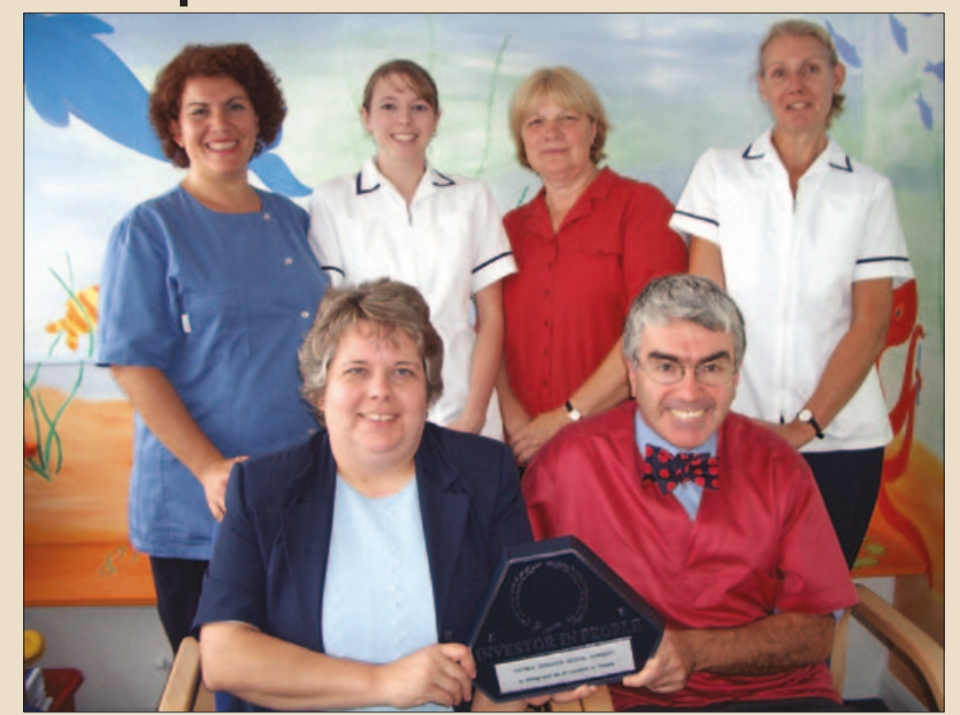

Dartford Road Dental Centre in West Dartford has been recognised as an Investor in People. Dr Patrick Donohoe (front row right) who has been a dentist in Dartford for 21 years and his wife Dr Amalia Liguori (back row far left) attended a six-month course and a residential weekend. The practice works as a team and exchanges ideas and information to maintain a high standard. 